$\xi=$ 줄

\title{
Knowledge and practice of vital pulp therapy in young permanent teeth among general dental practitioners in Kerman, Iran
}

\author{
Lida Pishbin ${ }^{1 *}$, Fatemeh Sadat Sajadi ${ }^{1}$, Maryam Mahmoudi ${ }^{2}$, Hassan Shahabinejad ${ }^{3}$ \\ ${ }^{1}$ Department of Pediatric Dentistry, School of Dentistry, Kerman University of Medical Sciences, Kerman, Iran \\ 2 Private Practice, Kerman, Iran \\ ${ }^{3}$ Department of Endodontic, Kerman Dental School, Kerman University of Medical Sciences, \\ Kerman, Iran \\ *Corresponding author E-mail: lida.pishbin95@gmail.com
}

\begin{abstract}
The dental pulp is the living tissue of the tooth and its vitality is essential for long-term tooth survival. The vitality or non-vitality of the pulp as well as the presence or absences of a radicular pathology determine the type of pulp therapy. The knowledge of the dentist is important in selecting and carrying out a proper complete treatment. Therefore, this study was conducted to assess general dental practitioner`s (GDP) knowledge of indication, methods and prognosis of vital pulp therapy (VPT) for young permanent teeth (YPT).

Method A total of 160 GDPs from dental clinics and offices in Kerman participated in this descriptive cross-sectional study. Data were collected using an initial questionnaire consisted of 15 items examining the knowledge and practice of indication, methods and prognosis of VPT for YPT among GDPs. The participants were asked to choose from the provided answers.

Result of 160 questionnaires 154 were used for final evaluation. The overall obtained average score of the total items of the questionnaire was $4.53 \pm 3.56$. There was not any significant correlation between the knowledge of indication, examination, diagnosis, patients selection, effective factors in success of treatment and gender, number of the years since graduation and the university where the degree was obtained for VPT among GDPs. While knowledge of selecting the right materials for pulp-capping was significantly correlated with the number of the years since graduation and the university where the degree was obtained.

Conclusion Although GDPs' level of knowledge in regard to VPT is not favorable, the time since graduation and place of education influenced the suitable material selection for pulp capping. Hence, GDPs, who perform pulp therapy, need to keep themselves updated with these procedures.
\end{abstract}

Keywords: Vital Pulp Therapy; General Dental Practitioner; Knowledge; Young Permanent Teeth

\section{Introduction}

The dental pulp is the living tissue of the teeth and its vitality is essential for long-term tooth survival. Vital pulp therapy (VPT) is a treatment which is conducted to preserve the vitality and function of the coronal or remaining radicular pulp tissue that has been compromised but not destroyed by trauma, caries, or restorative procedures in a healthy state (Ghoddusi et al. 2014). VPT, namely direct pulp capping, partial pulpotomy, or full pulpotomy, should be performed only in teeth with reversible pulpitis with no periapical pathologies or in teeth with either mechanical pulp exposure or recently traumatic pulp exposure (Makowiecki et al. 2014). In the case of pulp exposure, promoting healing of the pulp tissue and facilitating the formation of reparative dentin in order to preserve the pulp vitality and health are the main aims of the treatment (Aguilar \& Linsuwanont 2011) In VPT procedures, the local irritants are removed and a protective material is directly or indirectly placed over the pulp (Akhlaghi \& Khademi 2015). An overlying tight-sealed restoration is required after these treatments in order to decrease bacterial leakage from the restoration-dentin interface. The aim of conducting VPT is to accomplish complete root canal therapy after treatment of reversible pulp injury in order to promote root development and apical closure (Cohenca et al. 2013). VPT is particularly important in the young permanent teeth whose apical root is not completely developed. Due to the high healing capacity of pulp tissue in young patients compared to older patients, VPT has only been recommended for young patients (Ward 2000). The best practices for the management of cariesassociated pulp disease in young permanent and primary teeth are yet to be established (Hilton et al. 2013). The vitality or nonvitality of the pulp as well as the presence or absence of a radicular pathology determine the type of pulp therapy (Ward 2000). In most of the cases, the lack of knowledge of the dentist is a key factor in incomplete treatment of pulp disease. Untreated carious lesions involving the pulp lead to necrosis of the pulp which often affects the per-iradicular tissues accompanied with pain and discomfort for the patient (Aguilar \& Linsuwanont 2011). The cariously exposed pulp is treated based on the maturity of the tooth. Various VPT techniques are indirect pulp treatment (IPT), direct pulp treatment (DPT), partial pulpotomy, and full pulpotomy in vital permanent teeth. Promoting apexogenesis is the classical aim of conducting pulpotomy in young permanent teeth (Cohenca et al. 2013). VPT is still a controversial subject with regard to judgment criteria and the status of the pulp at the time of treatment, optimal technique and treatment outcomes (Aguilar \& Linsu- 
wanont 2011). General dental practitioners (GDPs), who are working in dental clinics and offices, receive numerous patients who require VPT. Selecting a suitable approach and treatment by the GDPs is critical considering the high incidence of dental carries in young permanent teeth, especially first permanent molar, as well as high traumatic incidence in anterior young teeth associated with inadequate root development. Therefore, a preliminary survey among a selected group of general dentists in Kerman city was conducted to assess their knowledge of pulp therapy in young permanent teeth.

\section{Methods and materials}

This was a descriptive cross-sectional study. A total of 154 general dental practitioners (GDP) from dental clinics and offices in Kerman participated in the present study. Data were collected using a 15-item questionnaire. The participants were asked to choose from the answers provided in the questionnaire.

The initial questionnaire consisted of 16 items examining the knowledge and practice of indication, methods and prognosis of VPTfor young permanent teeth among GDP. The initial questionnaire was evaluated by 11 endodontists and pediatric dentists who were asked to give their opinion about the reasonability of each item by choosing one of the following options; very appropriate, appropriate, neutral, inappropriate, and very inappropriate. The questionnaire was then modified based on their comments before being distributed between the GDP. Internal consistency and Cronbach's alpha factor were used for final evaluation. In this case, the questionnaires were given to 20 dentists in a 10 day period and aCronbach's alpha factor of 0.78 was obtained.

The questionnaire used in the present study was designed to examine five different aspects; items 1-5 were related to the indications, examination, diagnosis and patient selection in VPT for young permanent teeth, items 6-8 examined the success and practical implementation of various vital pulp therapies for immature permanent teeth, items 9-11 investigated the materials selected for pulp capping, items 12 and 13 studied the subsequent restorative treatments and items 14 and 15 were related to the outcome, follow up and evaluation of the treatment success.
The studied population included the GDP from dental clinics and offices who were willing to participate in the study. A census survey was used to select the participants by referring to the medical council and the treatment deputy of Kerman University of Medical Sciences. In total, 160 GDP out of 238 who practice in Kerman participated in this study. All the participants were assured that their details would remain confidential. After collecting the questionnaires, those without demographic information or with more than $50 \%$ unanswered questions were excluded. Consequently, 154 questionnaires out of 160 were used for statistical analysis. To evaluate the answered questionnaires, each of the correct, wrong and neutral answers was given a positive, a negative and zero score, respectively.

\subsection{Statistical analysis}

The data were analysed in SPSS V. 20 using student's t-test and ANOVA. Descriptive statistics and 95\% confidence level were used for qualitative data. A value of $\mathrm{P}<0.05$ was considered as statistically significant.

\section{Results}

Of 160 questionnaires which was distributed among general dental practitioners in Kerman, aiming to examine their knowledge and practice of indication, methods and prognosis of vital pulp therapy for immature permanent teeth, the information of 154 was used for the final evaluation. The other 6 questionnaires were excluded from the study since they were not fully answered. In total, 73 female $(47.7 \%)$ and 81 male $(52.6 \%)$ GDPs participated in the present study. The number of years since the participants were graduated varied from 1 to 24 years with an average of 5 years. The participants were either graduated from one of the ten universities in Iran or they took graduate courses in Iran after graduation from a university abroad. The frequency distribution of the participants based on their gender, number of years since the graduation and the university they attended is shown in Table. 1.

Table 1: Frequency Distribution of the General Dental Practitioners Who Participated in this Study Based on Their Gender, Number of the Years since Graduation and University where Their Degree was obtained

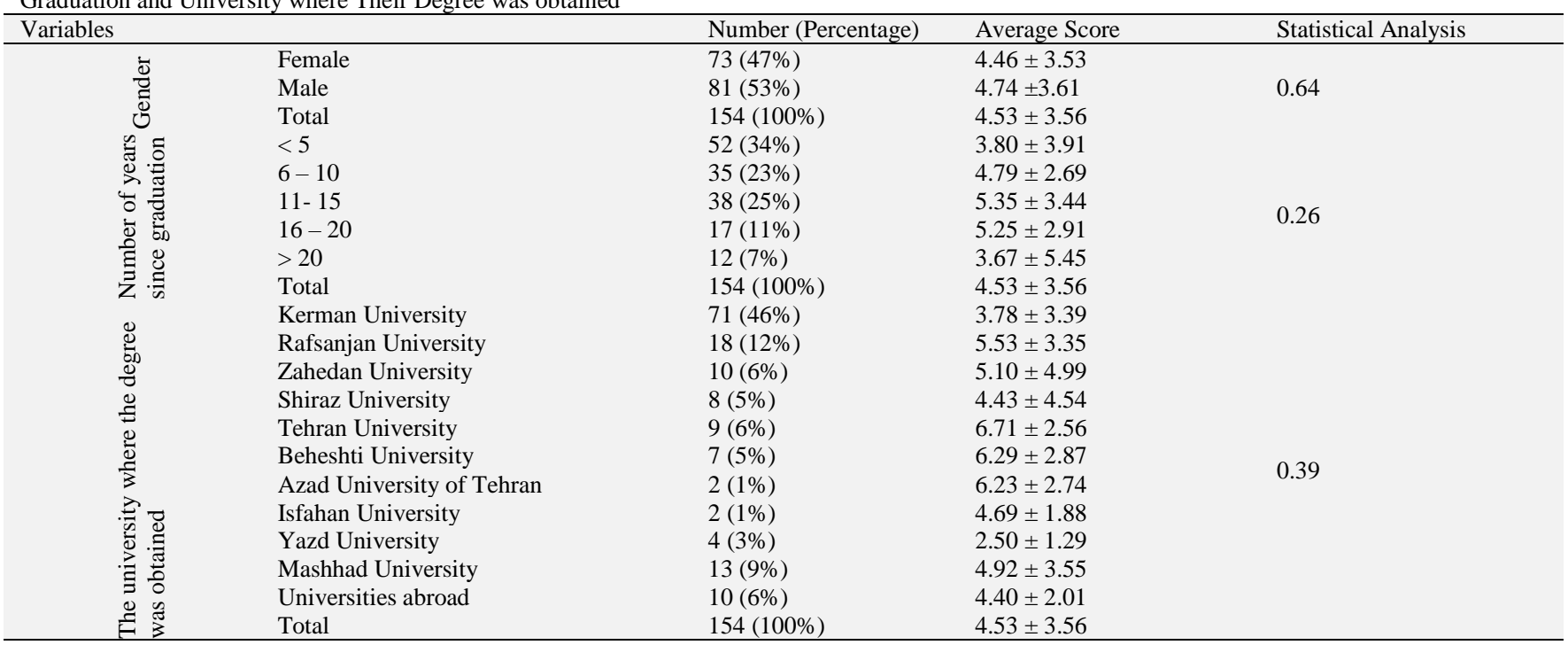

\subsection{Dentists' knowledge of the questionnaires and the relation between their knowledge and the three varia- bles}

The obtained average score of the 15 questions asking about the knowledge was $4.53 \pm 3.56$. The average scores for female and male participants were $4.46 \pm 3.53$ and $4.74 \pm 3.61$, respectively.
In total, 93of the 154 participants in this study agreed that attending the regular refresher courses on the subject of vital pulp therapy is necessary and beneficial. Furthermore, the findings of the present study showed that there was not any significant correlation between the knowledge score and gender $(\mathrm{p}=0.64)$, number of the years since graduation $(\mathrm{p}=0.26)$ and the university where the degree was obtained $(\mathrm{p}=0.39)$. The related data are shown in Table. 2. 
3.2. Dentists' knowledge of indication, examination, diagnosis and patients selection for vital pulp therapyand the relation between their knowledge and the three variables

The first five items of the questionnaire were designed to evaluate the knowledge and of indication, examination, diagnosis and pa- tients selection forVPT of young permanentteeth among GDPs. The average score obtained for these items was $1.28 \pm 1.45$. Statistical analysis did not reveal any significant correlation between the mentioned knowledge and gender $(\mathrm{p}=0.32)$, number of the years since graduation $(\mathrm{p}=0.40)$ and the university where the degree was obtained $(\mathrm{p}=0.81)$. The detailed data are shown in Table 2,3 and 4 .

Table 2: Correlation between the Knowledge Score of the General Dental Practitioners of Kerman and Their Gender

\begin{tabular}{|c|c|c|c|c|c|c|c|c|c|c|c|c|}
\hline \multirow{2}{*}{$\begin{array}{l}\text { Item } \\
\text { Num- } \\
\text { ber }\end{array}$} & \multicolumn{3}{|c|}{ Correct Answer } & \multicolumn{3}{|c|}{ Wrong Answer } & \multicolumn{3}{|c|}{ Neutral Answer } & \multicolumn{3}{|c|}{ No Answer } \\
\hline & $\begin{array}{l}\text { Male } \\
\mathrm{N}(\%)\end{array}$ & $\begin{array}{l}\text { Female } \\
\mathrm{N}(\%)\end{array}$ & $\begin{array}{l}\text { Total } \\
\mathrm{N}(\%)\end{array}$ & $\begin{array}{l}\text { Male } \\
\mathrm{N}(\%)\end{array}$ & $\begin{array}{l}\text { Female } \\
\mathrm{N}(\%)\end{array}$ & $\begin{array}{l}\text { Total } \\
\mathrm{N}(\%)\end{array}$ & $\begin{array}{l}\text { Male } \\
\mathrm{N}(\%)\end{array}$ & $\begin{array}{l}\text { Female } \\
\mathrm{N}(\%)\end{array}$ & $\begin{array}{l}\text { Total } \\
\mathrm{N}(\%)\end{array}$ & $\begin{array}{l}\text { Male } \\
\mathrm{N}(\%)\end{array}$ & $\begin{array}{l}\text { Female } \\
\mathrm{N}(\%)\end{array}$ & $\begin{array}{l}\text { Total } \\
\mathrm{N}(\%)\end{array}$ \\
\hline 1 & $\begin{array}{l}72(46.75 \\
\%)\end{array}$ & $\begin{array}{l}79(51.30 \\
\%)\end{array}$ & $\begin{array}{l}\text { 151(98.05 } \\
\%)\end{array}$ & $1(0.65 \%$ & $2(1.29 \%$ & $3(1.94 \%)$ & $0(0 \%)$ & $0(0 \%)$ & $0(0 \%)$ & $0(0 \%)$ & $0(0 \%)$ & $0(0 \%)$ \\
\hline 2 & $\begin{array}{l}7(4.54 \% \\
)\end{array}$ & $\begin{array}{l}11(7.14 \\
\%)\end{array}$ & $\begin{array}{l}18(11.69 \\
\%)\end{array}$ & $\begin{array}{l}65(42.21 \\
\%)\end{array}$ & $\begin{array}{l}68(44.16 \\
\%)\end{array}$ & $\begin{array}{l}133(86.36 \\
\%)\end{array}$ & $0(0 \%)$ & $\begin{array}{l}2(1.29 \% \\
)\end{array}$ & $\begin{array}{l}2(1.29 \% \\
)\end{array}$ & $\begin{array}{l}1(0.65 \\
\%)\end{array}$ & $0(0 \%)$ & $\begin{array}{l}1(0.65 \\
\%)\end{array}$ \\
\hline 3 & $\begin{array}{l}64(41.56 \\
\%)\end{array}$ & $\begin{array}{l}74(48.05 \\
\%)\end{array}$ & $\begin{array}{l}138(89.61 \\
\%)\end{array}$ & $\begin{array}{l}8(5.19 \% \\
)\end{array}$ & $5(3.25 \%$ & $13(8.44 \%$ & $1(0.65 \%$ & $2(1.29 \%$ & $3(1.94 \%$ & $\begin{array}{l}3(1.94 \\
\%)\end{array}$ & $\begin{array}{l}1(0.65 \\
\%)\end{array}$ & $\begin{array}{l}4(2.59 \\
\%)\end{array}$ \\
\hline 4 & $\begin{array}{l}54(35.6 \\
\%)\end{array}$ & $\begin{array}{l}56(36.36 \\
\%)\end{array}$ & $\begin{array}{l}110(71.43 \\
\%)\end{array}$ & $10(6.5 \%$ & $\begin{array}{l}16(10.39 \\
\%)\end{array}$ & $\begin{array}{l}26(16.88 \\
\%)\end{array}$ & $6(3.89 \%$ & $9(5.84 \%$ & $\begin{array}{l}15(9.47 \\
\%)\end{array}$ & $0(0 \%)$ & $0(0 \%)$ & $0(0 \%)$ \\
\hline 5 & $\begin{array}{l}19(12.34 \\
\%)\end{array}$ & $\begin{array}{l}25(16.24 \\
\%)\end{array}$ & $\begin{array}{l}44(28.57 \\
\%)\end{array}$ & $\begin{array}{l}44(28.57 \\
\%)\end{array}$ & $\begin{array}{l}45(29.22 \\
\%)\end{array}$ & $\begin{array}{l}89(57.79 \\
\%)\end{array}$ & $\begin{array}{l}10(6.50 \\
\%)\end{array}$ & $\begin{array}{l}10(6.50 \\
\%)\end{array}$ & $\begin{array}{l}20(12.9 \\
\%)\end{array}$ & $0(0 \%)$ & $\begin{array}{l}1(0.65 \\
\%)\end{array}$ & $\begin{array}{l}1(0.65 \\
\%)\end{array}$ \\
\hline 6 & $\begin{array}{l}50(32.50 \\
\%)\end{array}$ & $\begin{array}{l}55(35.71 \\
\%)\end{array}$ & $\begin{array}{l}105(68.18 \\
\%)\end{array}$ & $\begin{array}{l}14(9.09 \\
\%)\end{array}$ & $\begin{array}{l}14(9.09 \\
\%)\end{array}$ & $\begin{array}{l}28(18.18 \\
\%)\end{array}$ & $\begin{array}{l}9(5.84 \% \\
)\end{array}$ & $\begin{array}{l}11(7.14 \\
\%)\end{array}$ & $\begin{array}{l}20(12.90 \\
\%)\end{array}$ & $0(0 \%)$ & $\begin{array}{l}1(0.65 \\
\%)\end{array}$ & $\begin{array}{l}1(0.65 \\
\%)\end{array}$ \\
\hline 7 & $\begin{array}{l}25(16.23 \\
\%)\end{array}$ & $\begin{array}{l}25(16.23 \\
\%)\end{array}$ & $\begin{array}{l}50(32.50 \\
\%)\end{array}$ & $\begin{array}{l}44(28.57 \\
\%)\end{array}$ & $\begin{array}{l}51(33.12 \\
\%)\end{array}$ & $\begin{array}{l}95(61.69 \\
\%)\end{array}$ & $4(2.59 \%$ & $5(3.25 \%$ & $9(5.84 \%$ & $0(0 \%)$ & $0(0 \%)$ & $0(0 \%)$ \\
\hline 9 & $\begin{array}{l}48(31.17 \\
\%)\end{array}$ & $\begin{array}{l}48(31.17 \\
\%)\end{array}$ & $\begin{array}{l}96(62.34 \\
\%)\end{array}$ & $\begin{array}{l}17(11.4 \\
\%)\end{array}$ & $\begin{array}{l}14(9.09 \\
\%)\end{array}$ & $\begin{array}{l}31(20.13 \\
\%)\end{array}$ & $\begin{array}{l}8(5.19 \% \\
)\end{array}$ & $\begin{array}{l}19(12.34 \\
\%)\end{array}$ & $\begin{array}{l}27(17.53 \\
\%)\end{array}$ & $0(0 \%)$ & $0(0 \%)$ & $0(0 \%)$ \\
\hline 10 & $\begin{array}{l}25(16.23 \\
\%)\end{array}$ & $\begin{array}{l}31(20.13 \\
\%)\end{array}$ & $\begin{array}{l}56(36.36 \\
\%)\end{array}$ & $\begin{array}{l}14(9.09 \\
\%)\end{array}$ & $\begin{array}{l}9(5.84 \% \\
)\end{array}$ & $\begin{array}{l}23(14.93 \\
\%)\end{array}$ & $\begin{array}{l}33(21.43 \\
\%)\end{array}$ & $\begin{array}{l}39(25.32 \\
\%)\end{array}$ & $\begin{array}{l}72(46.75 \\
\%)\end{array}$ & $\begin{array}{l}1(0.65 \\
\%)\end{array}$ & $\begin{array}{l}2(1.30 \\
\%)\end{array}$ & $\begin{array}{l}3(1.95 \\
\%)\end{array}$ \\
\hline 11 & $\begin{array}{l}43(27.92 \\
\%)\end{array}$ & $\begin{array}{l}52(33.76 \\
\%)\end{array}$ & $\begin{array}{l}95(61.69 \\
\%)\end{array}$ & $\begin{array}{l}19(12.34 \\
\%)\end{array}$ & $\begin{array}{l}19(12.34 \\
\%)\end{array}$ & $\begin{array}{l}38(24.67 \\
\%)\end{array}$ & $\begin{array}{l}11(7.14 \\
\%)\end{array}$ & $10(6.5 \%$ & $\begin{array}{l}21(13.64 \\
\%)\end{array}$ & $0(0 \%)$ & $0(0 \%)$ & $0(0 \%)$ \\
\hline 12 & $\begin{array}{l}35(22.72 \\
\%)\end{array}$ & $\begin{array}{l}35(22.72 \\
\%)\end{array}$ & $\begin{array}{l}70(45.40 \\
\%)\end{array}$ & $\begin{array}{l}37(24.03 \\
\%)\end{array}$ & $\begin{array}{l}39(25.33 \\
\%)\end{array}$ & $\begin{array}{l}76(49.35 \\
\%)\end{array}$ & $1(0.65 \%$ & $\begin{array}{l}7(4.54 \% \\
)^{2}\end{array}$ & $\begin{array}{l}8(5.19 \% \\
)\end{array}$ & $0(0 \%)$ & $0(0 \%)$ & $0(0 \%)$ \\
\hline 13 & $\begin{array}{l}66(42.86 \\
\%)\end{array}$ & $\begin{array}{l}75(48.70 \\
\%)\end{array}$ & $\begin{array}{l}141(91.65 \\
\%)\end{array}$ & $\begin{array}{l}6(3.90 \% \\
)\end{array}$ & $\begin{array}{l}4(2.59 \% \\
)\end{array}$ & $10(6.5 \%)$ & $1(0.65 \%$ & $\begin{array}{l}2(1.29 \% \\
)\end{array}$ & $\begin{array}{l}3(1.94 \% \\
)\end{array}$ & $0(0 \%)$ & $0(0 \%)$ & $0(0 \%)$ \\
\hline 14 & $\begin{array}{l}44(28.57 \\
\%)\end{array}$ & $\begin{array}{l}54(35.06 \\
\%)\end{array}$ & $\begin{array}{l}98(63.63 \\
\%)\end{array}$ & $\begin{array}{l}24(15.58 \\
\%)\end{array}$ & $\begin{array}{l}18(11.69 \\
\%)\end{array}$ & $\begin{array}{l}42(27.27 \\
\%)\end{array}$ & $5(3.25 \%$ & $8(5.19 \%$ & $\begin{array}{l}13(8.44 \\
\%)\end{array}$ & $0(0 \%)$ & $\begin{array}{l}1(0.65 \\
\%)\end{array}$ & $\begin{array}{l}1(0.65 \\
\%)\end{array}$ \\
\hline 15 & $\begin{array}{l}\text { 63(40.90 } \\
\%)\end{array}$ & $\begin{array}{l}73(47.40 \\
\%)\end{array}$ & $\begin{array}{l}136(88.32 \\
\%)\end{array}$ & $3(1.94 \%$ & $\begin{array}{l}4(2.59 \% \\
)\end{array}$ & $7(4.54 \%)$ & $6(3.90 \%$ & $\begin{array}{l}4(2.59 \% \\
)\end{array}$ & $10(6.5 \%$ & $\begin{array}{l}1(0.65 \\
\%)\end{array}$ & $0(0 \%)$ & $\begin{array}{l}1(0.65 \\
\%)\end{array}$ \\
\hline 16 & $\begin{array}{l}52(33.76 \\
\%)\end{array}$ & $\begin{array}{l}41(26.62 \\
\%)\end{array}$ & $\begin{array}{l}93(60.39 \\
\%)\end{array}$ & $\begin{array}{l}4(2.59 \% \\
)\end{array}$ & $10(6.5 \%$ & $14(9.09 \%$ & $\begin{array}{l}17(11.04 \\
\%)\end{array}$ & $\begin{array}{l}29(18.83 \\
\%)\end{array}$ & $\begin{array}{l}46(29.87 \\
\%)\end{array}$ & $0(0 \%)$ & $\begin{array}{l}1(0.65 \\
\%)\end{array}$ & $\begin{array}{l}1(0.65 \\
\%)\end{array}$ \\
\hline
\end{tabular}

Table 3: Correlation between the Knowledge Score of the General Dental Practitioners of Kerman and the Number of the Years since Their Graduation

\begin{tabular}{|c|c|c|c|c|c|c|c|}
\hline \multirow{2}{*}{$\begin{array}{l}\text { Variables } \\
\text { Groups of questions }\end{array}$} & & \multicolumn{6}{|c|}{ Number of years since graduation } \\
\hline & & $<5$ & $6-10$ & $11-15$ & $16-20$ & $>20$ & Total \\
\hline \multirow{3}{*}{$\begin{array}{l}\text { First Group } \\
\text { Questions 1-5 }\end{array}$} & $\mathrm{N}(\%)$ & $50(23.46 \%)$ & $34(22.07 \%)$ & $37(24.02 \%)$ & $16(10.38 \%)$ & $11(7.14 \%)$ & $148(96.10 \%)$ \\
\hline & Score & $1.06 \pm 1.42$ & $1.50 \pm 1.23$ & $1.52 \pm 1.55$ & $1.21 \pm 1.49$ & $0.81 \pm 1.83$ & $1.28 \pm 1.45$ \\
\hline & P Value & 0.40 & & & & & \\
\hline \multirow{3}{*}{$\begin{array}{l}\text { Second Group } \\
\text { Questions 6-8 }\end{array}$} & $\mathrm{N}(\%)$ & $52(33.76 \%)$ & $35(22.72 \%)$ & $37(24.02 \%)$ & $17(11.03 \%)$ & $12(7.79 \%)$ & $153(99.35 \%)$ \\
\hline & Score & $0.46 \pm 1.50$ & $-0.17 \pm 1.36$ & $-0.27 \pm 1.70$ & $0.31 \pm 1.49$ & $0.16 \pm 1.64$ & $0.09 \pm 1.55$ \\
\hline & P Value & 0.17 & & & & & \\
\hline \multirow{2}{*}{$\begin{array}{l}\text { Third Group } \\
\text { Questions 9-11 }\end{array}$} & Score & $0.38 \pm 2.04$ & $1.2 \pm 1.1$ & $1.58 \pm 1.13$ & $1.43 \pm 1.26$ & $0.001 \pm 1.76$ & $1.02 \pm 1.61$ \\
\hline & P Value & 0.006 & & & & & \\
\hline \multirow{3}{*}{$\begin{array}{l}\text { Fourth Group } \\
\text { Questions 12-13 }\end{array}$} & $\mathrm{N}(\%)$ & $52(33.76 \%)$ & $35(22.72 \%)$ & $38(24.67 \%)$ & $17(11.03 \%)$ & $12(7.79 \%)$ & $154(100 \%)$ \\
\hline & Score & $0.53 \pm 1.32$ & $1.14 \pm 1.03$ & $0.97 \pm 1.06$ & $0.81 \pm 0.98$ & $0.50 \pm 0.90$ & $0.80 \pm 1.14$ \\
\hline & P Value & 0.11 & & & & & \\
\hline \multirow{3}{*}{$\begin{array}{l}\text { Fifth Group } \\
\text { Questions 14-15 }\end{array}$} & $\mathrm{N}(\%)$ & $51(33.11 \%)$ & $35(22.72 \%)$ & $38(24.67 \%)$ & $16(10.38 \%)$ & $12(7.79 \%)$ & $152(98.701 \%)$ \\
\hline & Score & $1.00 \pm 1.17$ & $1.08 \pm 0.98$ & $1.35 \pm 0.94$ & $1.37 \pm 1.14$ & $1.75 \pm 0.86$ & $1.20 \pm 1.06$ \\
\hline & P Value & 0.16 & & & & & \\
\hline
\end{tabular}


Table 4: Correlation between the Knowledge Score of the General Dental Practitioners of Kerman and the University where Their Degree was obtained

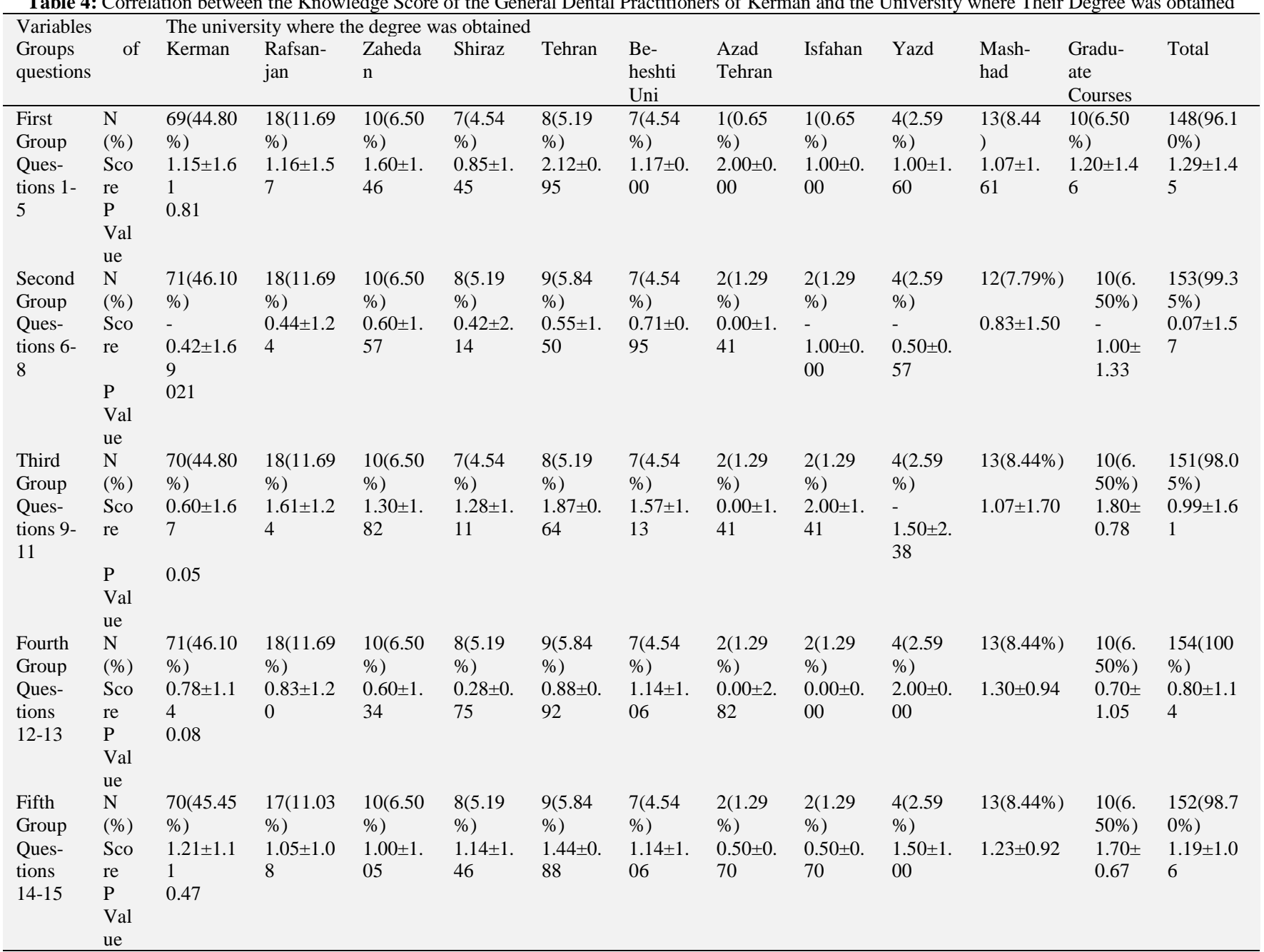

3.3. Dentists' knowledge of effective factors in success of treatment and practical implementation of various vital pulp therapies and the relation between their knowledge and the three variables

In items 6-8 of the questionnaire, the knowledge of effective factors in success of treatment and critical points in practical implementation of various vital pulp therapies among GDPs were questioned. The average score of these questions was $0.09 \pm 1.53$. No significant correlation was detected between the mentioned knowledge and gender $(\mathrm{p}=0.57)$, number of the years since graduation $(p=0.17)$ and the university where the degree was obtained $(p=0.21)$. Table $x x, x x$ and $x x$ illustrate the detailed data.

3.4. Dentists' knowledge of the materials selection for pulp-capping for various vital pulp therapies and the relation between their knowledge and the three variables

The participant were questioned about choosing the right materials for pulp-capping for various vital pulp therapies in items 9-11 of the questionnaire. The average score of $1.31 \pm 1.61$ was obtained for these items. Statistical analysis showed no significant correlation between the mentioned knowledge and the gender $(\mathrm{p}=0.21)$. However, the knowledge of the materials selection for pulpcapping was significantly correlated with the number of the years since graduation $(\mathrm{p}=0.05)$ and the university where the degree was obtained $(p=0.006)$. The data are shown in Table $x x, x x$ and $\mathrm{xx}$.
3.5. Dentists' knowledge of the subsequent restorative treatments in vital pulp therapy and the relation between their knowledge and the three variables

Items 12 and 13 of the questionnaire were designed to evaluate the knowledge of the subsequent restorative treatments in vital pulp therapy among GDPs. The average score of these items was 0.84 \pm 1.14 . Moreover, the findings of this study showed that there was not any significant correlation between the knowledge score and gender $(p=0.17)$, number of the years since graduation $(p=0.11)$ and the university where the degree was obtained $(p=0.08)$. The related data are shown in Table $\mathrm{xx}, \mathrm{xx}$ and $\mathrm{xx}$.

3.6. Dentists' knowledge of the outcome, follow up and evaluation of the treatment success and the relation between their knowledge and the three variables

In items 14 and 15, GDPs were asked about the outcome, follow up and evaluation of the treatment success in vital pulp therapy. The average score obtained for these questions was $1.24 \pm 1.04$. Statistical analysis did not reveal any significant correlation between the mentioned knowledge and gender $(p=0.64)$, number of the years since graduation $(\mathrm{p}=0.16)$ and the university where the degree was obtained $(p=0.47)$. The detailed data are shown in Table 5. 
Table 5: Frequency of the Items of the Questionnaire Answered by the General Dental Practitioners of Kerman Who Participated in this Study

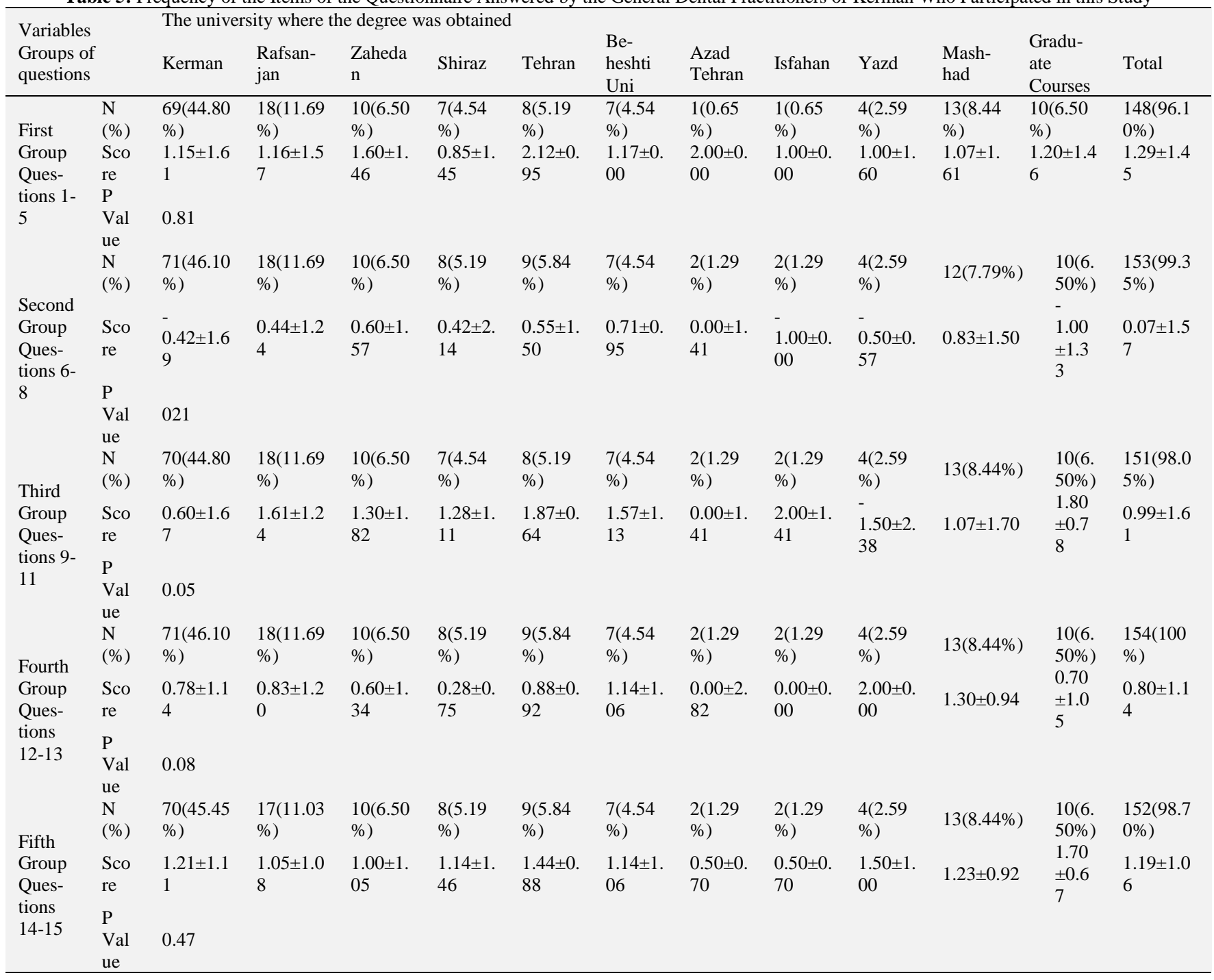

Items 1-5 were related to the indications, examination, diagnosis and patient selection in vital pulp therapy for immature permanent teeth

Items 6-8 examined the success and practical implementation of various vital pulp therapies for immature permanent teeth Items 9-11 investigated the materials selected for pulp-capping Items 12 and 13 studied the subsequent restorative treatments Items 14 and 15 were related to the outcome, follow up and evaluation of the treatment success.

\section{Discussion}

The primary aim of the present study was to determine whether GDPs who work in dental clinics and offices in Kerman city chose an optimal technique and treatment of VPT in young permanent teeth. GDPs were selected as the target group to assess their knowledge of VPT in young permanent teeth. The evaluation was carried out using a questionnaire whose content was confirmed by pediatric dentists and endodontists. Previous studies have shown that post-graduation training affect the adhesive system selection, the choice of vital bleaching treatment, application of rubber dam for composite restoration as well as the choice of post for endodontically treated teeth (Demarco et al. 2013a; 2013b; Nascimento et al. 2013).

The focus of the present study was to evaluate the knowledge and the experience of the GDPs of young permanent teeth treatment because of the high incidence of dental carries in young permanent teeth, especially first permanent molar, as well high traumatic incidence in cranial young teeth associated with inadequate root development. One of the major focuses of attention in dental care is to develop strategies in VPT, which aim to maintain vitality and function of the dentine-pulp complex (Tziafas et al. 2000). Further to the items of the questionnaire, the GDPs have also been asked about the necessity of regular refresher courses post-graduation. In the present study, $60.39 \%$ (93 of the 154) of the participants agreed that attending the regular refresher courses on the subject of VPT is necessary and beneficial. The overall obtained average score of the 15 questions (score 15 to -15 ) asking about the knowledge was $4.53 \pm 3.56$. The highest and lowest score was 15 and 4 , respectively. The average scores of the female GDP's knowledge were lower than those of the male participants $(4.46 \pm$ 3.53 versus $4.74 \pm 3.61)$. However, there was no significant difference between the scores with respect to gender. These results revealed low level score of participants' awareness and knowledge of VPT. The low level score of awareness results in choosing unsuitable treatment approaches for VPT. A total of $85 \%$ of the participants in this study have been graduated less than 10 years ago from two universities which are located in Kerman Province. Therefore, the practice of young and native GDPs, who present most inadequate, experience of GDPs may have caused obtaining low average score of their knowledge in this study. The vitality or non-vitality of the pulp which is determined based of the clinical diagnosis of the normal pulp (symptom free and normally responsive to vitality testing) and symptomatic or asymptomatic irreversible pulpitis (vital inflamed pulp is incapable of healing), or necrotic pulp specify the indications, objectives, and type of pulp therapy (Ward 2000; Guideline on Pulp Therapy 2011).

The average score obtained for the first five items of the questionnaire that designed to evaluate the knowledge of indication, exam- 
ination, diagnosis and patients selection for VPT of young permanent teeth among GDPs was $1.28 \pm 1.45$ while the average score obtained for the knowledge of effective factors in success of treatment and critical points in practical implementation of various VPTs among GDPs was $0.09 \pm 1.53$. There was not any significant correlation between the mentioned knowledge and gender, number of the years since graduation and the university where the degree was obtained.

In the present study, the average score of $1.31 \pm 1.61$ was obtained by GDPs for choosing the right materials for pulp-capping in various VPT in young permanent teeth. Although, the knowledge of the material selection for pulp-capping was not significantly correlated with gender, it was significantly correlated with the number of the years since graduation and the university where the degree was obtained. We found that GDPs with up to 10 years of gap since their graduation had higher score of knowledge of right material selection for pulp capping as well as those who have been graduated from top universities. The overall results of this study showed that the dentists' characteristics (time in clinical practice and the University of Graduation) influenced their decisions in relation to the right material selection for pulp-capping. These GDPs could be more updated with the recent literatures. The influence of the time since graduation and place of work on the clinical conduction related to caries removal and choice of materials has also been reported by Chisini et al. (2015). VPT, which includes stepwise excavation, indirect pulp capping, direct pulp capping, miniature pulpotomy, partial/Cvek pulpotomy and coronal/complete pulpotomy, has been considered an ultraconservative treatment in modern endodontics (Asgary et al. 2014; Smail-Faugeron et al. 2016). There are various types of VPT, one of which is known as direct pulp capping. Sealing the exposed pulp with biocompatible and antibacterial dressing are necessary in direct pulp capping (Fallahinejad Ghajari et al et al. 2010). Dressing characteristics include ease of handling, sealing ability, marginal adaptation, long term stability and stimulation of calcified bridge (Zarrabi et al. 2010; Sarkis-Onofre et al. 2015). There has been a discrepancy between general dentists regarding pulp capping material selection in VPT which has been recently reported in Brazilian general dentists (Chisini et al. 2015). They have pointed out that none of the dentists who are working exclusively in the public health system choose expensive material, such as mineral trioxide aggregate (MTA), as the capping material. In fact, MTA is far more expensive than calcium hydroxide-based materials and it is not available in the majority of the basic units in the public system (Sarkis -Onofre et al. 2015). The lack of information about the promising results of applying MTA and its price can explain its low indication for GDPs with less than 10 years since their graduation or those who have been graduated from different universities.

The two latest items of the questionnaire were designed to evaluate the knowledge of the subsequent restorative treatments and outcome, follow up and evaluation of the treatment success in VPT. Statistical analysis did not reveal any significant correlation between the mentioned knowledge and gender, number of the years since graduation and the university where the degree was obtained.

\section{Conclusion}

Although GDPs' knowledge of VPT is not favorable, the time since graduation and place of education influenced the right material selection for pulp capping. Since most of the GDPs are regularly performing pulp therapy in young permanent teeth, it is recommended that special attention should be paid to this issue during their academic education in order to train better skilled dentists. Moreover, GDPs need to be frequently updated about these procedures.

\section{Conflicts of interest}

There are no conflicts of interest.

\section{Financial support and sponsorship}

None.

\section{References}

[1] Ghoddusi J, Forghani M, Parisay I. New Approaches in Vital Pulp Therapy in Permanent Teeth. Iran Endod J 2014;9(1):15-22.

[2] Makowiecki P, Trusewicz M, Tyszler L, Buczkowska-Radlińska J. The vital pulp therapy in permanent teeth. Ann Acad Med Stetin 2014; 60(2):80-8

[3] Aguilar P, Linsuwanont P. Vital pulp therapy in vital permanent teeth with cariously exposed pulp: A systematic review. J Endod 2011; 37:581-7 https://doi.org/10.1016/j.joen.2010.12.004.

[4] Akhlaghi $\mathrm{N}$ and Khademi A. Outcomes of vital pulp therapy in permanent teeth with different medicaments based on review of the literature. Dent Res J (Isfahan) 2015; 12(5): 406-17. https://doi.org/10.4103/17353327.166187

[5] Cohenca N, Paranjpe A, Berg J. Vital pulp therapy. Dent Clin North Am 2013; 57:59-73 https://doi.org/10.1016/j.cden.2012.09.004

[6] Ward J. Vital pulp therapy in cariously exposed permanent teeth and its limitations. Aust Endod J 2002; 28(1):29-37. https://doi.org/10.1111/j.1747-4477.2002.tb00364.x.

[7] Hilton TJ, Ferracane JL, Mancl L. Northwest Practice-based Research Collaborative in Evidence-based Dentistry (NWP). Comparison of $\mathrm{CaOH}$ with MTA for direct pulp capping: A PBRN randomized clinical trial. J Dent Res 2013; 92:16S-22 https://doi.org/10.1177/0022034513484336.

[8] Demarco FF, Baldissera RA, Madruga FC, Simoes RC, Lund RG, Correa MB, Cenci MS. Anterior composite restorations in clinical practice: findings from a survey with general dental practitioners. J App Oral Sci 2013a; 21:497-504. https://doi.org/10.1590/1679-775720130013.

[9] Demarco FF, Conde MC, Ely C, Torre EN, Costa JR, Fernandez MR, Tarquinio SB. Preferences on vital and nonvital tooth bleaching: a survey among dentists from a city of Southern Brazil. Braz Dent J 2013b; 24:527-31. https://doi.org/10.1590/0103-6440201302152.

[10] Nascimento GG, Correa MB, Opdam N, Demarco FF. Do clinical experience time and postgraduate training influence the choice of materials for posterior restorations? Results of a survey with Brazilian general dentists. Braz Dent J 2013; 24:642-6. https://doi.org/10.1590/01036440201302361.

[11] Tziafas D, Smith AJ, Lesot H. Designing new treatment strategies in vital pulp therapy. J Dent 2000; 28(2):77-92. https://doi.org/10.1016/S0300-5712(99)00047-0.

[12] Guideline on Pulp Therapy for Primary and Immature Permanent Teeth. AAPD Reference Manual. 2011-12;33:212-9

[13] Chisini LA, Conde MC, Correa MB, Dantas RV, Silva AF, Pappen FG, Demarco FF. Vital Pulp Therapies in Clinical Practice: Findings from a Survey with Dentist in Southern Brazil. Braz Dent J 2015; 26(6):566-71 https://doi.org/10.1590/0103-6440201300409.

[14] Asgary S, Fazlyab M, Sabbagh S, Eghbal MJ. Outcomes of different vital pulp therapy techniques on symptomatic permanent teeth: a case series. Iran Endod J 2014; 9(4):295-300.

[15] Smaïl-Faugeron V, Porot A, Muller-Bolla M, Courson F. Indirect pulp capping versus pulpotomy for treating deep carious lesions approaching the pulp in primary teeth: a systematic review. Eur J Paediatr Dent 2016; 17(2):107-12.

[16] Fallahinejad Ghajari M, Asgharian Jeddi T, Iri S, Asgary S. Direct pulp-capping with calcium enriched mixture in primary molar teeth: a randomized clinical trial. Iran Endod J 2010; 5(1):27-30.

[17] Asgary S, Parirokh M, Eghbal MJ, Ghoddusi J. SEM evaluation of pulp reaction to different pulp capping materials in dog's teeth. Iran Endod J 2007; 1(4):117-23.

[18] Zarrabi MH, Javidi M, Jafarian AH, Joushan B. Histologic assessment of human pulp response to capping with mineral trioxide aggregate and a novel endodontic cement. J Endod 2010; 36(11):1778-81. https://doi.org/10.1016/j.joen.2010.08.024.

[19] Sarkis-Onofre R, Pereira-Cenci T, Opdam NJ, Demarco FF. Preference for using posts to restore endodontically treated teeth: findings from a survey with dentists. Brazilian Oral Research 2015; 29:1-6. https://doi.org/10.1590/1807-3107BOR-2015.vol29.0001. 